4. Лозинський М. Галичина в рр. 1918-1920. Відень, 1922. 228 с.

5. Чубата М. Конституційне законодавство ЗУНР: до питання про автентичні та неавтентичні тексти «Тимчасового Основного закону» від 13 листопада 1918 р. Часопис Київського університету права. 2014. Вип. 3. С. 48-51.

6. За державну незалежність Галичини. Чому українська Галичина не може прийти під Польщу. Зладив д-р М. Лозинський. Відень, 1921. $43 \mathrm{c}$.

7. Бош Е. Национальное правительство и Советская власть в Украине. М.: Книгоизд-во «Коммунист», 1919. 56 с.; Майоров М. Из истории революционной борьбы на Украине (1914-1919). К. : Держвидав, 1922. 108 с.

8. Лозинський М. В десятиріччя галицької революції: (Галичина, Антанта й Рад. Союз). Червоне право. Х., 1928. № 23. С. 1089-1098.

9. Лозинський М. В десятиріччя галицької революції: Факти й спроба оцінки. Червоний шлях. Х.,1928. № 11. С.180-191.

10. Лозинський М. Річниця уярмлення Галичини. Червоний шлях. 1928. № 3. С. 91-102.

DOI https://doi.org/10.30525/978-9934-588-92-1-17

\title{
УНІФІКАЦІЯ ДЕРЖАВНОГО АПАРАТУ ТА ПРАВА УКРАЇНИ-ГЕТЬМАНЩИНИ ЯК ЗАСІБ ЛІКВІДАЦЇ̈ ÏÏ АВТОНОМІЇ: ІСТОРИКО-ПРАВОВА РОЗВІДКА
}

Шевченко О. В.

аспірант

Харківського національного університету імені В. Н. Каразіна м. Харків, Україна

Традиційно процеси ліквідації Гетьманщини, уніфікації ії державного апарату та права із загальноросійськими у вітчизняній та зарубіжній історіографії пов'язують $з$ добою правління Катерини II. Саме 3 набуттям нею влади, як зазначає В. М. Горобець, «взаємини українського Гетьманату та російського самодержавства набули якісно нового звучання». Саме тоді розпочинається абсолютно новий та, як виявилося пізніше, завершальний етап їхнього розвитку, «коли українська сторона була представлена власною ранньоновою державною організацією та, 
відповідно, певною мірою консолідованою навколо неї елітною верствою українського суспільства» [1, с. 236-237].

Безперечно, програмною метою державного будівництва для імператриці була саме унітарна держава та суцільна універсалізація управління нею: усі державні інститути, усе законодавство держави на iii думку мали однаково ефективно слугувати для всіх категорій імперських підданих, незалежно від місця їхнього мешкання: живуть вони у Санкт-Петербурзі, Казані або ж в Україні-Гетьманщині. Відмінності національного характеру («нравов») в принципі визнавалися, та вважалися настільки неважливими, що на них не варто було звертати уваги. Як зазначав 3. Когут, імператриця «вірила, що 3 адміністративною інтеграцією і більш однорідним іiі розвитком регіональні відмінності зникнуть» [2, с. 192, 196]. Кінцева мета царського уряду, вочевидь, полягала у тому, що М. Раєв назвав «інституційною русифікацією», тобто такою інтеграцією, яка «...мала б призвести до однорідності, спершу адміністративної й економічної, згодом інституційної і соціальної, і нарешті культурної» [1, с. 237]. Заради досягнення такої однорідності Катерина II протиставляла новий раціональний порядок (за ії визначенням, «найкращий з усіх порядків») давнім «феодальним» привілеям окремих історичних регіонів. Для неї ці останні були допотопними реліктами, які тільки перешкоджали досягненню ii основної мети - створенню унітарної, добре врегульованої держави [2, с. 192].

Відтак, маніфест імператриці від 10 (22) листопада 1764 р. про ліквідацію інституту гетьманства, на відміну від виданих 3 цього приводу попередніх указів російських правителів, уже не містив вказівок щодо тимчасовості його дії. Гетьман був змушений зректися булави, про що наприкінці 1764 року було оповіщено в царському маніфесті, яким «задля добра українському народу» засновувалася Друга Малоросійська Колегія на чолі з президентом, він же і генералгубернатор. Тож 1764 року, за словами М. Аркаса, «кінчається хоч i гірке, та все ж схоже на самостійне, життя України» [3]. Як слушно зауважував історик, представник української діаспори у США З. Когут, скасування посади гетьмана було лише одним з аспектів загальної політики Катерини II стосовно регіональної автономії [2, с. 192].

У процесі пошуку цих самих «зручних способів» урядом Катерини II було взято курс на поступову уніфікацію державних порядків колишньої Гетьманщини та асиміляцію іiі суспільства: «...коли в Малоросії гетьмана не буде, слід докласти всіх зусиль, щоб доба та ім'я гетьманів щезли...» [4, с. 62]. 
Для вирішення першого завдання було створено Другу малоросійську колегію, яка одночасно і замінила собою гетьманську форму правління, і увібрала в себе елементи колишньої державної структури Гетьманату (зокрема, вже 1764 р. колегією було поглинуто вищий виконавчий орган при гетьманському правлінні - Генеральну військову канцелярію, 1765 р. підпорядковано Генеральний військовий суд, а два роки по тому в колегіальні департаменти було перетворено Генеральну лічильну комісію, Канцелярію малоросійського скарбу, Канцелярію генеральної артилерії тощо [5, с. 36-37]).

Найдошкульнішим ударом по автономії України стала ліквідація Запорозької Січі. 29 червня 1775 року з'явився указ Сенату про знищення Січі й згодом маніфест цариці. В ньому населенню сповіщалося: «Ми схотіли через це оголосити у всій нашій Імперії, до загального сповіщення нашим всім вірнопідданим, що Січ Запорізька в кінець вже ліквідована, з винищенням на майбутній час і самої назви Запорізьких козаків», 3 причини образи «нашої імператорської величності через вчинки та непокору ... нашим височайшим велінням» [4, c. 64].

Реформи не оминули й реєстрове козацтво. Як зазначає О.В. Кресін [6, с. 169], у 1768 р. замість комплектування козацтва з представників козацьких родин наказом президента Малоросійської колегії Румянцева запроваджено особисту військову повинність козацтва [7, с. 88]. У червні 1774 р. командування козацькими військами було передано до Військової колегії. У 1779-1782 рр. на Лівобережну Україну було поширено «Основний закон для адміністрації губерній Російської імперії» від 7 листопада 1775 p., що ліквідував полковий територіально-адміністративний устрій, позбавив козацьку старшину адміністративної влади та зрівняв рядове козацтво в судовому плані 3 державними селянами [6, с. 169]. Усі козацькі інституції та посади, пов'язані з невійськовими справами, ліквідовувалися. Імператорським указом від 28 червня 1783 р. у Лівобережній Україні замість козацьких було створено десять регулярних кавалерійських полків, що комплектувалися та розміщувалися за територіальним принципом.

Отже, за допомогою уніфікації державного апарату і права УкраїниГетьманщини було знищено ії автономію, права, вольності та привілеї населення, раніше неодноразово підтвердженні царськими заявами та договорами.

\section{Література:}

1. Горобець В.М. Ліквідація автономії Гетьманату Катериною II як синтез російської правлячої династії традиціоналізму та новаторства 78 
української політики. Україна і Росія в історичній ретроспективі: Нариси в 3 m. T. 1: Українські проекти в Російській імперії. Київ. : Наук. думка, 2004. 504 с.

2. Kohut Z. Ukraine: from Autonomy to Integration (1654-1930's). Conquest and Coalescence: The Shaping of the State in Modern Europe. London, 1991. P. 190-214.

3. Аркас М. Історія України-Русі. Київ: Вища школа, 1993. 413 с.

4. Ільєнко I.O. В пазурах у двоглавого орла: Українство під царським гнітом (1654-1917). Київ : Ярославів Вал, 2004. 228 с.

5. Горобець В. М., Струкевич О. К. Українсько-російські політичні відносини XVII-XVIII ст.: тенденції, характер, етапи. Украӥнський історичний журнал. 1997. № 1. С. 22-43.

6. Кресін О. В. Нормативно-правове регулювання козацького станового права. Історія украӥнського козацтва: Нариси: У 2 т. Т. 2. I Редкол. : В. А. Смолій (відп. ред.) та ін. К.: Вид. дім «КиєвоМогилянська академія», 2007. С. 160-173.

7. Путро А. И. Левобережная Украина в составе Российского государства во второй половине XVIII в. (Некоторые вопросы социально-зкономического и общественно-политического развития). Киев: Вища школа, 1988. 140 с. 